\title{
Peter Eubanks, The limits of Renaissance Aesthetics: Jean Lemaire de Belges's 1504 «Plainte du Désiré»
}

\section{Filippo Fassina}

\section{(2) OpenEdition}

1 Journals

\section{Edizione digitale}

URL: http://journals.openedition.org/studifrancesi/6576

DOI: 10.4000/studifrancesi.6576

ISSN: 2421-5856

\section{Editore}

Rosenberg \& Sellier

\section{Edizione cartacea}

Data di pubblicazione: 1 septembre 2010

Paginazione: 349

ISSN: 0039-2944

\section{Notizia bibliografica digitale}

Filippo Fassina, «Peter Eubanks, The limits of Renaissance Aesthetics: Jean Lemaire de Belges's 1504 «Plainte du Désiré»», Studi Francesi [Online], 161 (LIV | II) | 2010, online dal 30 novembre 2015, consultato il 10 janvier 2021. URL: http://journals.openedition.org/studifrancesi/6576 ; DOI: https:// doi.org/10.4000/studifrancesi.6576

Questo documento è stato generato automaticamente il 10 janvier 2021.

\section{(c)}

Studi Francesi è distribuita con Licenza Creative Commons Attribuzione - Non commerciale - Non opere derivate 4.0 Internazionale. 


\title{
Peter Eubanks, The limits of
}

\section{Renaissance Aesthetics: Jean Lemaire de Belges's 1504 «Plainte du Désiré»}

\author{
Filippo Fassina
}

\section{NOTIZIA}

PETER EUBANKS, The limits of Renaissance Aesthetics: Jean Lemaire de Belges's 1504 «Plainte du Désiré», «Bibliothèque d'Humanisme et Renaissance», LXX, 1 (2008), pp. 147-155.

1 L'A. offre un'analisi accurata del poema Plainte du Désiré scritto da Jean Lemaire de Belges nel 1504 per celebrare la morte di Luigi di Lussemburgo. L'opera, strutturata in forma di dialogo fra la Pittura e la Retorica, offre lo spunto per una riflessione sui limiti della rappresentazione artistica. In primo luogo, viene sottolineata l'impossibilità di esprimere attraverso l'arte ciò che realmente l'artista prova, in particolar modo riguardo alla sofferenza, che trova una rappresentazione convincente soltanto attraverso il silenzio. Lemaire de Belges viene accostato, quindi, a un altro grande poeta del sentimento, Guillaume Machaut, che nei suoi componimenti pone l'accento sulla difficoltà di riprodurre autenticamente un sentimento tramite espressioni letterarie. Altro limite che Lemaire ammette è l'impossibilità di rappresentazione dell'infinito $\mathrm{e}$ soprattutto dell'infinita sofferenza che si prova perdendo una persona cara. In conclusione, questo studio evidenzia all'interno dell'opera di Lemaire de Belges un'interessantissima riflessione sui sentimenti del poeta, sul ruolo dell'artista e sui limiti dell'arte espressiva, che va ben al di là degli schemi retorici previsti dal genere letterario. 